\title{
Deep Blue: \\ kultur, computer, skak
}

af programmør Mikael Hansen 1

IBM's forskningslaboratorium i Yorktown Heights, New York har tidligere vundet verdensmesterskabet mellem skakcomputere med maskinen Deep Thought. Prototypen på dens efterkommer Deep Blue havde premiere i Forskerbyen Symbion, København den 24. febr. 1993, arrangeret af IBM og KSU (Københavns Skak Union), og på Det kongelige Biblioteks vegne overværede jeg arrangementet, hvis ydre ramme (24.-28. febr. 1993) især gjaldt en match på fire partier mod stormester Bent Larsen og hvis indre ramme (24.-26. febr. 1993) var et seminar om fremtidens computerteknologi.

Åbningstalerneved skakscenen iSymbions lysgård holdtes af forskningsminister Svend Bergstein, Nordisk Konferencechef for IBM, Ebbe Johansen og Bent Larsen. Og så var festlighederne undervejs. Med de hvide brikker foretog Svend Bergstein symbolsk Larsens første træk (1.e2-e4) mod Deep Blue i det første matchparti. Publikumsinteressen var stor fra begyndelsen, fjernsynet, radioen og avisjournalister var til stede, computerskak udstillingsområdet var vel besøgt, og stemningen i presse-, VIP- og de øvrige organisationslokaler boblede og sydede som dagen tog til. En lille kerne af seminardeltagere trak sig fra tid til anden tilbage - til en lidt af́sides liggende sal, hvor fremtidens teknologi stod på tapetet.

\section{IBM Deep Blue projektet}

Overblikket blev serveret af projektets administrator Dr. C.J. Tan ${ }^{2}$. Udgangspunktet var en skakmaskine med stor regnekraft opnået gennem implementering af parallelle processorer. Computerskakkens historie blev skitseret, og algoritmerne og hardwaren bag en moderne skakcomputer blev omtalt. 


\section{Skalérbare Parallelle Systemer}

Dr. Zeev Barzilai ${ }^{3}$ gik nærmere ind på, hvorledes morgendagen ville blive præget af den høje ydeevne, som udviklingen af parallel processor teknologien giver mulighed for. Grundet de helt nye anvendelsesområder har IBM afset store ressourcer til denne teknologi. Barzilais foredrag gik overvejende på den interne hardwarestruktur omkring de parallelle processorer. Barzilai mente iøvrigt, at neurale netværk er betragteligt mindre velegnede til eksempelvis en skakcomputer end parallelle processorer er det.- Styring af lufttrafik er et specifikt eksempel, om hvilket der blev holdt særskilt foredrag senere på dagen. I interviewet med Dr. Hsu nedenfor kom-mer vi også i forbindelse med Deep Blue ind på den konkrete anvendelse af skalérbare parallelle processorer.

\section{PowerPC}

Efter frokosten, hvor jeg sad til bords med hardwareeksperterne Barzilai og David Tuttle 4 , fortsatte sidstnævnte med PowerPC som et eksempel på fremtidens teknologi baseret på RISC teknologien. PowerPC projektet er en alliance mellem IBM, Apple og Motorola (et venskab, som Tuttle muntrede sig med at gentage indtil flere gange) om at anvende avanceret teknologi til at fremtage en arbejdsstation, der vil kunne tilbyde en ydeevne, som er mange gange større end dagens tilsvarende PC'er.

Den epokegørende chip er iøvrigt uafhængig af det operativsystem, som styrer dens maskine, og som en konkret spådom forventede Tuttle, at chippens basismodel (601, andre fremtidige er 603 og 620) med sine $60 \mathrm{MHz}$ vil optrædei en A pple Macintosh ved årsskiftet og i en IBM PC ved begyndelsen af næste år. Med sin omfattende samling af $\mathrm{PC}^{\prime}$ er og MAC'er har Det kongelige Bibliotek god grund til at se frem til disse computeres ankomst.

\section{Seminariedagen}

Det er gængs kutyme ved foredrag af den slags, at anvendte plancher foreligger i ringbind med kopisider til brug for de enkelte seminarister senerehen, men ikke i dette tilfælde, og i bakspejlet kan det noteres, at det formodentlig hænger sammen at IBM var lidt vel tidligt ude med arrangementet. Den fremtid, der tales om, ville næppe blive til nutid blot et par måneder senere. 


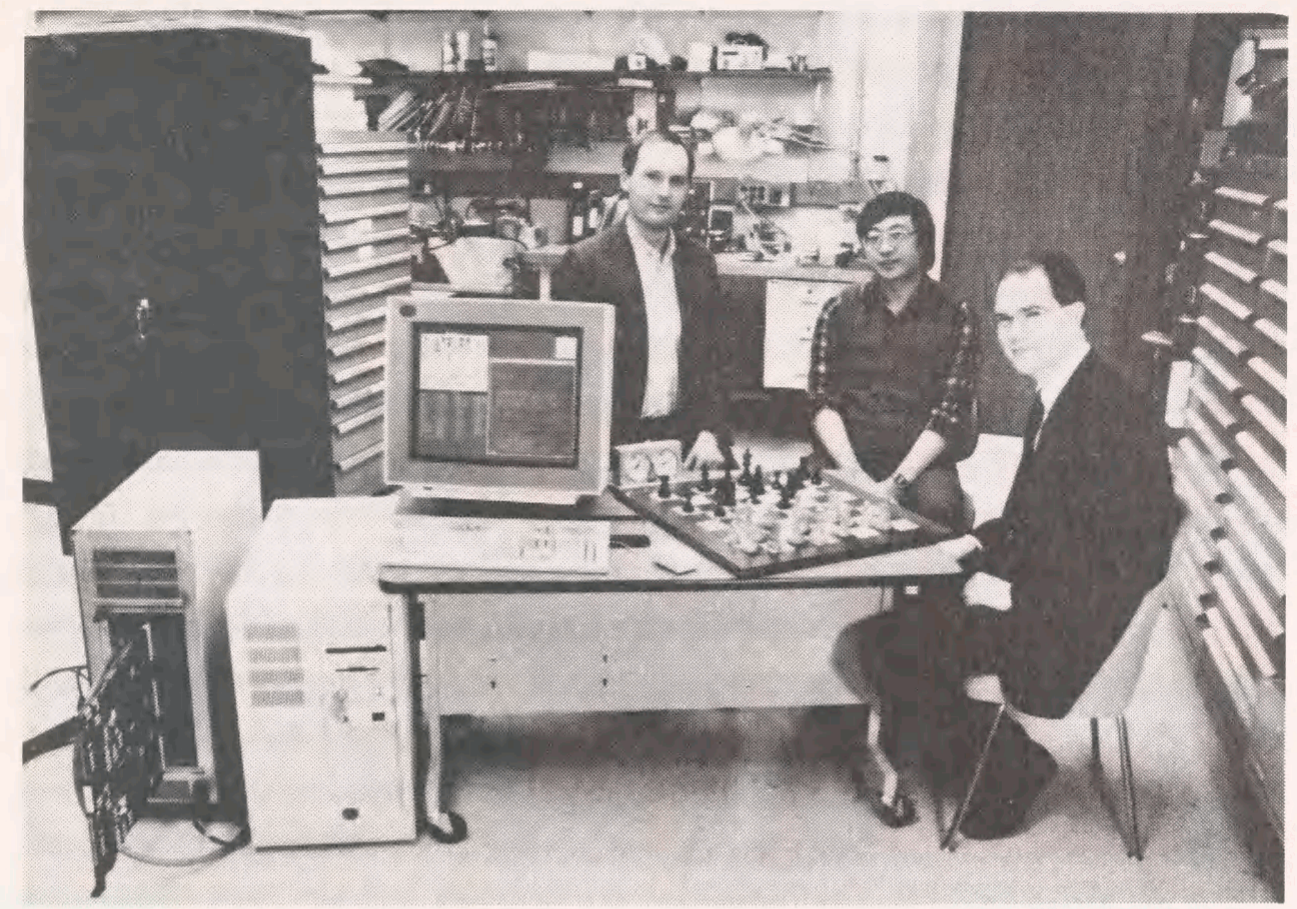

Murray Campbell, Feng-hsiung Hsu og A. Joseph Hoane, Jr.

\section{Den ydre verden i Symbion}

En præcist spillende Bent Larsen måtte tage størstedelen af dagen og 43 træk i brug, før sejren var hjemme. Verdens stærkeste skakcomputer fik sig en dukkert, og Deep Blue programmørerne (Feng-hsiung Hsu, Murray Campbell og A. Joseph Hoane,Jr.) påtog sig ekstra natarbejde forud for det andet matchparti to dage senere.

Fredag den 26. februar 1993 havde de fået bedre hold på programmet, og ud på eftermiddagen fik Deep Blue remis i overkanten. Menneskets angst for at blive overhalet af maskinen, som udfaldet af det første parti lagde en dæmper på, fik fornyet næring. Ikke mindst computerens større succes øgede den publikumsinteresse, der fra starten har været stor, og dét mærkedes klart ved det efterfølgende pressemøde, hvor den tydeligt meget trætte Larsen gennemgik og kommenterede partiet for folket. Min hensigt var at interviewe stormesteren, og jeg var så heldig at få en ti minutters tid alene med ham mellem pressemødets afslutning og optagelsen af en radioudsendelse. 


\section{Stormester Bent Larsen ${ }^{5}$}

(Interviewet på dansk, uforkortet, men let redigeret)

På det klassiske sporgsmål, om skak er kunst, videnskab, spil eller sport, ... (har du engang svaret, at skak er ...)

Altsammen. Altsammen! Deter detaltsammen. Men jo ikkealtid på samme tid.

Hvis en computer spiller skak, er det så også en tilsvarende kulturel udfoldelse?

Dét ... dét ved jeg ikke. For altså, der er jo folk, der definerer, at de der maskiner ikke kan tænke. Og dét siger jeg bare, jeg ved ikke, om det er rigtigt, for jeg har set dem lave nogle analyser, der ligner6. Men om det er kulturel udfoldelse, det er meget ... meget filosofisk og meget fremtidsbetonet spørgsmål, så det kan man sige bare for sjov. Så er der nogen, der protesterer, men det er det vel ikke på den måde. Hvad er kultur for noget, ikke sandt?

Det betyder jo dyrkning7.

Ja, og det betyder vaner og jeg ved ikke hvad.

Og det betyder også ændring af vaner.

Ja, det gør det helt bestemt.

Hvad synes du?

Ja, jeg har ikke noget imod, at man opfatter det, at mennesker har kunnet lavet en maskine, som kan spille mægtigt godt skak som en kulturbegivenhed. Det har jeg ikke noget imod.

Jeg tænker på ... dét store spring, som folk snakker om, det er enten da en computer vinder over en stormester første gang, eller den måske vinder over en verdensmester den første gang, eller den vinder over verdensmesteren hver gang. Eksisterer et sådant springende punkt for dig? 8

Nej! Lige sådan i vore dage ... først, så vinder en maskine et fem minutters parti, så vinder den et halv times parti og så noget dér. Nej, dét synes jeg ikke.

Og verdensmesterens styrke svinger jo også?

Ja, ja.

Og rating ...

Pyt med det. At tage rating som udtryk for spillestyrke er ikke videnskabeligt. Det er uvidenskabeligt simpelthen. Men vi ved allesammen, hvad vi snakker om, hvis vi snakker om gamle Bronstein, eller om Kasparov. Men at tage deres ratingtal, dét synes jeg altså er pjat. 
I din åbningstale citerede du Botvinnik ${ }^{9}$ fra 1964.

Ja, Botvinnik sagde i 1964 under olympiaden i Israel, at snart kunne Sovjet sende fire maskiner til at vinde olympiaden, og jeg snakkede meget med Botvinnik i begyndelsen af 1965 lige efter det der, fordi vi var en måned på simultanturné sammen. Og han var så begejstret, at han sagde, at når det lykkes at lave maskinen til en stærk skakspiller, så vil programmørerne eller systemanalytikerne af dét lære så meget, at de kan lave andre meget vanskelige programmer. Det næste, sagde han, blev et økonomisk program, og så er det, jeg siger, at dette kom altså for sent til at redde Sovjetunionens økonomiske system. Men han var dengang meget optimistisk og arbejdede sammen med i hvert tilfælde én - eller det kan være, at der var flere matematikere. Og året efter var han knap så optimistisk, fordi de matematikere forstod ingenting. Men altså dengang i 1964 var han én af dem, der sagde det stærkest: meget snart, så ville de have fire verdensmestre i form af maskiner. Og dét gik så i hvert tilfælde ikke i opfyldelse. Men manden lever jo endnu knap tredive år efter, og han er et par og firs. Men jeg tror nok, at han stadigvæk er meget optimistisk med det der. Det skal han have lov til.

Jeg tror, at det var $i$ 1960, da Tal smadrede Botvinnik på dronningefløjen med et tårnoffer, jeg tror det var a 6 eller b6, et meget berømt parti 10 .

Der er flere berømte partier ...

Ja, men der var ét særligt. Jeg tror det, var b6 til a6, og så ...

Nå ja, det parti hvor Tal står skidt, og ...?

Vistnok.

Det er en Caro-Kann, og Botvinnik kikser lige før træk nr. 40?

Ja. En sådan svipser kunne en computer aldrig spille.

Nej, det er rigtigt.

Det var en simpel overseelse.

Ja, ja. Men der er så meget andet, som Botvinnik kunne, som dén ikke kan.

Det er jeg sikker på!

Ja. (store smil)

Apropos springende punkt eller ikke springende punkt. Har skakken en fremtid efter...?

Ork ja! Ork ja. Det ødelægger ikke spor. Der er jo også både maskiner og dyr, der løber rundt, og mennesker, der ... Se bare, olympiaden er en stor begivenhed hver gang. 


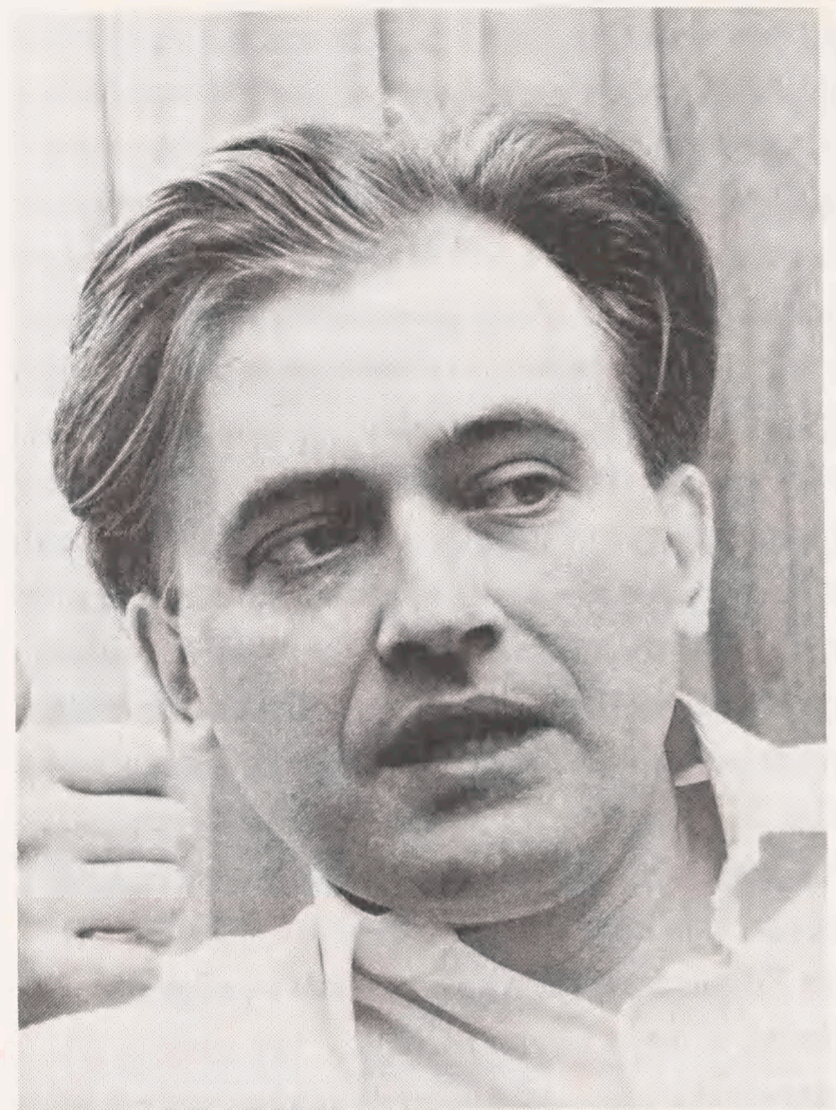

Stormester Bent Larsen

Og fordi du mere end de fleste andre stormestre har udtrykt dig med en mere generel, hvad skal vi sige, kulturel viden: musik ...

Det kan da godt være, at jeg har det, det ved jeg ikke. Der er selvfølgelig nogle fæle eksempler ind imellem ... (stor latter)

Lad os tage en parallel til spørgsmailet om Har skakken en fremtid. Har bogen en fremtid?

Ja, det mener jeg, den har. Men jeg fik engang et brev fra en skakspiller der sagde: bogens tid er forbi. Og ham gik jeg altså ikke i samarbejde med. Han ville lave lydbånd og videobånd, og jeg ved ikke hvad. Og når man starter et brev sådan, er det ikke en god start for et samarbejde, som altså heller ikke kom i stand. Nej, det der med, at bogens tid er forbi, dét er noget vrøvl. Men vi kan da godt sige, at tidligere snakkede man om mikrofilm, og nu snakker man om disketter og mange andre ting. Bogen er stadigvæk udmærket. Der er meget at gøre. 
Som en samling af papirsider?

Ja, det tror jeg nok. Det er da udmærket, hvis man kan redde nogle træer og skove ved at gøre det hele til disketter ... Men jeg tror, at bogen fortsætter.

Har du været på Det kongelige Bibliotek?

Nej.

Men du kommer måske engang ...

Ja, hvad ved jeg ...

Hvis du bliver inviteret!

Jeg har engang modtaget noget fra Det kongelige Bibliotek, det var en overbibliotekar, hvis navn jeg selvfølgelig uforskammeligt har glemt. Han havde nemlig fået en fortegnelse fra Reykjavik over en særlig skakbogsamling, som de har deroppe. Og den vidste han ikke, hvad han skulle gøre med, så den sendte han til mig. Det var i og for sig meget fornuftigt (stort grin), men jeg synes, det er meget sjovt at have.

Lad mig sige tak!

Det var så lidt!

\section{Programmør Dr. Feng-hsiung Hsu ${ }^{11}$}

(Interviewet oversat fra engelsk og gengivet i lettere forkortet form)

(Indledende blev der trykket hænder med Dr. Campbell og A. Joseph Hoane, Jr., der var ved at gøre Deep Blue klar til aftenpartiet mod IM og DM Carsten Høi, og Dr. Hsu og jeg fandt et stille hjørne)

Hvor meget stærkere er Deep Blue end eksempelvis Chess 12 ?

Chess lå på omkring 2000. Deep Blue ligger langt højere. (Pressechefen gav mig en hurtigt beregnet afsluttende præstationsrating på 2560. Deep Thought lå på 2300)

Deep Blue programmet blev debugget $i$ nattetimerne (efter at Bent Larsen havde vundet det første parti). Har du fået sovet noget?

Lidt! Det var morsomt. Før matchen blev tilføjet ting i programmet, som måske ikke var testet tilstrækkeligt, så ... Vi har foretaget lidt standard debugging, ændret en smule i programmets adfærd og fået det til at køre hurtigere. Situationen er ikke afklaret.

Bent Larsen vandt det forste parti og fik remis $i$ det andet. Hvori ligger den væsentligste forskel $i$ baggrunden for de to resultater? 
I det første parti valgte maskinen en åbning (Firspringerspil), som formodentlig ikke passede til den. Larsen er kendt for at spille fint i den type stillinger, og vi troede, at maskinen ligeledes var egnet til den type åbninger, men vi tog fejl.

Det var kun et enkelt parti. Hvis der spilles tyve eller halvtreds partier med den åbning, ville Larsen vel næppe vinde alle partier?

Det er muligt.

Og halvtreds partier uden hensyn til åbning?

I det store og hele ville udfaldet blive meget godt for Larsen, fordi han efterhånden ville finde ud af, hvorledes maskinen var programmeret til at spille.

Således kan Larsen ændre sin stil med særligt henblik på computeren, hvilket omvendt ikke er muligt.

Maskinen ændrer sig kun for så vidt som programmørerne ændrer i programmet, dets adfærd, åbningsbiblioteket osv. I løbet af et parti kan en menneskelig spiller pludselig blive inspireret til at få en idé, og han siger måske til sig selv: det ser godt ud - og hvorfor spiller maskinen dét? Det beror på en vurdering, for maskinen kommer med et andet begrebssæt og idégrundlag end mennesket. Somme tider får maskinen en god idé, og man kan ikke bare sige med sikkerhed, at maskinen får en dårlig idé. Det er ikke altid at der er en tilstrækkelig god spiller til stede, som kan foretage en nødvendig bedømmelse af situationen. Og det sker, at programmet får en god idé, som programmørerne måske ikke havde forventet.

Og undertiden har computeren en dårlig dag ...

Ja, det er sandt.

Men det er ikke baseret på mangel på søvn ... Det hænger sammen med en given stillingstype og spillestil. Hvorledes har I tænkt Jer at forbedre programmets svage sider?

Man kan også prøve at lade programmet justere sin stil i forhold modstanderens, (således at det måske ikke spiller de objektivt bedste træk, men med fordel vælger de subjektivt bedste træk) det er en anden mulighed.

Deep Blue udfører en (Shannon type A) MiniMax Alpha-Beta 13 søgning.

Det betyder, at computeren kan foretage omkring 4 millioner instruktioner pr. sekund.

Og med en MiniMax Brute Force søgning ville det tage atten år $i$ stedet for ét sekund! Men nuomdage benytter stort set ethvert skakprogram Alpha-Betaalgoritmen. 
Vender vi tilbage til Chess, skiftede man mellem Brute Force og Alpha-Beta.

Chess går tilbage til sidste halvdel af 1970'erne, og programmet vandt ACM (Association for Computing Machinery) turneringerne fra 1970-8014. Og på tidspunkt træder Belleind på scenen. På sin højde havde Belle mesterstyrke, hvilket er intet i forhold til vore dage. En skakcomputer med den styrke kan nu købes for 200 dollars, måske mindre. Dengang kørte Belle iøvrigt på en dedikeret supercomputer.

Belle bleu programmeret af ATET (Bell Telephone Laboratories), Ken Thompson ...

Ken Thompson og Joe Condon.

Belle blev programmeret $i \mathrm{C}$...

Vistnok C og Mikro Assembler.

Og Deep Blue?

For tiden kalder vi det en Deep Blue prototype. Programmeringen er en blanding. Søgningen kan adskilles i to dele. Den ene foregår på en RISC / 6000 på de fjorten processorer. Med en ti ply (halvtræk) søgning foretages de øverste seks ply på softwareniveau og de resterende ply på hardware-processorerne. Ved skillelinien beder softwareværten en processor om at søge ud fra en given stilling samt returnere det bedste træk og dets værdi.

Hvilket programmeringssprog er softwareværten skrevet i?

C. Intet Assembler.

$\mathrm{C}++$ ?

Vi overvejede $\mathrm{C}++$ på et tidspunkt, men endnu har der ikke vist sig at være tid til denne ændring. Til de fjorten processorer har vi benyttet Mikro Assembler. Og det tog kun to uger at få skrevet denne kode, for der var kun ét at gøre, og det var en Alpha-Beta søgning og ikke så meget andet.

Tror du, at Deep Blue er klar til at møde.Kasparov 15 om måske to år?

Vi er i gang med en ny type enkelt chip processor, hvis kapacitet svarer til $\mathrm{ti}$ af de nuværende processorer. En dedikeret skakchip, jeg kalder den Blue chip - af oplagte grunde! (stort smil) Den kan udføre tre-fem millioner instruktioner pr. sekund.

Dr. Tan snakkede om springet fra fjorten til 1024 processorer.

Først skiftes der til den ny processor, en ny generation. Og derefter springet til 1024 parallelle processorer. Det vil give omkring tre-fem milliarder instruktioner pr. sekund, men miljøet med parallelle processorer vil lægge en mindre dæmper på hastigheden. Og på det tidspunkt tror vi, at computeren 
kan udspille Kasparov. Forud for dette står det klart for os, at vi tillige må alliere os med en professionel skaktræner.

På et tidspunkt kan programmet måske lære fra sig selv?

I en vis udstrækning. Men det kan være svært at afgøre! (stor latter)

Hvad er dit eget, Dr. Tan's eller IBM's formål med projektet?

Det er ikke så meget et AI (kunstig intelligens) projekt som det er et parallel processor projekt. Det er en del af et projekt om high performance parallelle processorer. Og det er selvfølgelig vældig god PR for IBM. Industrien omkring parallelle processorer vil vokse. Dagens mainframe kan blive morgendagens parallel processor workstation, det er én mulighed.

Hvorledes - bortset fra de parallelle processorer - adskiller Deep Blue computeren sig væsentligst fra en Intel 586 baseret PC?

Ét er den dedikerede hardware. Den ny prototype chip koster omkring 150.000 dollars pr. stk., og prisen på en teraflop/sekund maskine (tera-: en billion gange enheden) kommer således til at ligge omkring 20 millioner dollars, hvilket ikke er småpenge! (latter)

Du spiller selv lidt skak ...

Jeg kender reglerne, men spiller aldrig i turneringer.

Og mod Deep Blue?

Ikke så ofte, forstået som egentlige partier. Så ville mit ego blive knust! Men iøvrigt kender jeg programmet for godt. Undertiden spiller jeg mod andre skakprogrammer.

Du fik din Ph.D. i 1990 ?

Ja. Om parallelle processorer og Alpha-Beta søgealgoritmen.

Pådet tidspunkt var du allerede med på holdet omkring Deep Thought? (forløberen for Deep Blue)

Ja, det skete sideløbende, men begyndte for så vidt uafhængigt.

Tak skal du have.

(Partiet Carsten Høi mod Deep Blue begyndte her)

\section{International Mester Jens Kristiansen ${ }^{16}$}

(Interviewet på dansk og forkortet)

(Onsdag og torsdag spillede Jens Kristiansen og Bjarke Kristensen 17 samlet fire opvisningspartier mod Deep Blue. Den første dag gav to gevinster, den 
næste kun et halvt point, som Bjarke stod for)

Hvorledes vil du sammenligne din styrke med computerens?

Det er svært at sige. Der var nogle vanskeligheder i begyndelsen, men siden har programmørerne arbejdet stort set i døgndrift. De er nok kommet lidt tidligt ud. Man er ikke imponeret af de første partier. (onsdag)

Følte du, at du måtte omlægge din stil mod Deep Blue?

Ja, det måtte jeg vel. Jeg skal gøre lidt vold på mig selv. Vi har forberedt os meget grundigt, jeg er ligesom en træner for det danske hold. I det første parti spillede jeg, som man skal mod en computer. Man skal ikke ind i nogle stillinger, hvor det drejer sig om langsigtet planlægning. Man tager det roligt. Bjarkes og mine partier indgiki en hurtigskakmatch, og mit andet parti var det sidste, på et tidspunkt hvor matchen allerede var vundet, så jeg valgte bevidst en skarp Siciliansk, og i partiets midte viste programmet sin taktiske slagkraft. Men det var sjovt at prøve.

Hvis du ikke på forhaind vidste om modstanderen var et menneske eller en computer?

Det er et godt spørgsmål. Et menneske vil sjældent have den meget skarpe taktiske sans. Men (IM) Svend Hamann undervurderede computeren, dét sagde han selv, den spillede så underligt. Der var nogle små taktiske slip, og så gik det den anden vej.

Teknikken og skakkens (kulturelle) fremtid?

Jeg frygter ikke teknikken som sådan, jeg frygter mere hvad menneskene kan brugeden teknik til. (Den teknik, som menneskene har skabt!) Skak er ikke noget i sig selv, skak er det, som skakspillerne gør det til, skak eksisterer ikke som noget metafysisk begreb, der svæver over vandene. IBM pumper jo mange penge i det, fordi det er grundforskning i forhold til noget helt andet. Den helt typiske overskrift er jo det her med Menneske mod Maskine18, den bliver brugt mange steder, og den er jo også god. Det er én, der sælger og rører ved et eller andet. Jeg kan ikke komme i tanke om andre klassiske områder. Vægtløftere, der konkurrerer med en kran, det er jo det rene nonsens. Computeren er fundamentalt anderledes opbygget end den menneskelige hjerne, det der monster Deep Blue. Vi er nødt til at finde frem til de stærke sider ved den menneskelige intelligens. Det er spændende, vi lærer noget om os selv.

FIDE (verdensskakforbundet) har tilladt, at computere kan spille i turneringer. Jeg er ikke sikker på, at jeg selv vil bryde mig om at spille mod en 
computer i en rigtig turnering. (Bent Larsen har udtalt, at alle hængepartier i stormesterturneringer kan være forsvundet i løbet af bare fem år) En computer kan slå en verdensmester, men aldrig blive verdensmester.

Den kan ikke nyde det! (stor latter). Skal vi slutte med dét?

$\mathrm{Ja}$ !

\section{Slutspillet}

I det tredie parti spillede Larsen efter et lovende opspil et par upræcise træk og fik remis, i fjerdeog sidste parti kom han i vanskeligheder, men holdt remis. Manden vandt, men Maskinen gav ham kamp til stregen. Og Deep Blue vandt suverænt den sideløbende landskamp med 3-1 over IM Danielsen, IM Høi, GM Lars Bo Hansen og GM Larsen!

Og så er der det store spørgsmål om den frie vilje. Sidder Deep Blue tilbage med et lurende smil og snyder resten af os ${ }^{19}$ med et „I play chess, therefore I am!“'20 - Eller?21

\section{Noter}

1 Senior programmør i EDB-sektionen, Det kongelige Bibliotek; udover at deltage i den daglige drift af REX (Det kongelige Biblioteks bi-blioteksbase) varetages følgendespecialområder:PCprogrammering ( $\mathrm{C}++$ og Pascal), Macintosh (software og netværk) samt Database Publishing (DTP). I sin fritid skakspiller (mesterspiller, har deltaget i landsholdsklassen i korrespondan(eskak); har skrevet skakprogrammer (C++ og Pascal)

2 Ph.D, Senior Manager for Department of Concurrent Systems ved IBM T.J. Watson Research Centre

3 D.Sc. Director, VLSI and Parallel Systems ved IBM T.J. Watson Research Centre

4 arbejder ved projektkontoret i IBM Austin, Texas som leder af PowerChip projektet

5 Født 1935. Den største danske skak- spiller nogensinde. Tre gange vinder af VM interzone turneringer (1964, 1967, 1976), tre gange i VM kandidat-semifinaler (Tal 1966, Spassky 1968, Fischer 1971). Siden 1973 udenlandsdansker, først med bopæl i Las Palmas, Spanien, nu bosat i Buenos Aires, Argentina.

6 "Det er ikke nødvendigt at et program tænker som et menneske, når blot det handler ligesådan i en lignende situation" siger programmør og forfatter Herbert Schildt (som jeg besøgte i Illinois sommerferien 1992) i sin bog Artificial IntelligenceUsing C, Osborne McGraw-Hill 1987, p11

7 Forfatter og filos of Villy Sørensen:Uden mål - og med, Gyldendal 1973, p7: „Kultur betyder dyrkning, og hvad enten det er jorden eller guder man dyrker, er det kulturel virksomhed man udøver. Også resultatet af denne kulturelle virksomhed betegnes som kul 
tur, der altså bliver et navn for den dyrkede eller formede natur, både den ydre natur, der kultiveres ved hjælp af kultivatorer og andre hjælpemidler, og den menneskelige natur, der kultiveres gennem opdragelse i hjem, skole og $i$ alle de andre undervisningsanstalter."

8 VM Garri Kasparov, der var i København den 20. februar 1993, udtaler: "Jeg vil gerne stille op i en match mod en computer.Hvorforikke?"Og hellerikke han er enig med den danske stormester Curt Hansen (se iøvrigt diskussionen i Skakbladet 2, 1993, p14-15), der har skrevet, at skakcomputere vil ødelægge glæden ved skakspillet. - Men den dag, Kasparov for alvor taber til en computer $i$ en stor match, vil være skæbnesvanger: „Det vil være trist, ikke bare for mig, men for hele menneskeheden." VM 1948-57, 1958-60, 1961-63 Mikhail Botvinnik interesserede sig meget for kybernetik: videnskab, der beskæftiger sig med kontrol og styring af komplicerede systemer såsom maskiner

10 Tal-Botvinnik Verdensmesterskabsmatchen, 17. parti 26. april 1960, 39.,Dd5? (-,Ka8) 40.Tbxa6+ ,Kb8 41.Da4 10 . Hilary Thomas: Complete Games of Mikhail Tal, 1960-66 Arco Publishing, Inc. $1979, \mathrm{p} 7$.

11 Amerikaner af kinesisk oprindelse. Ph.D, arbejder ved IBM T.J. Watson Research Centre. Idémanden bag Deep Thought og Deep Blue. Har modtaget Mephisto prisen 1990 og ACM Grace Murray Hopper prisen 1991

12 David Slate og Larry Atkin, Northwestern University. I Evanston, en forstad til Chicago, Illinois. I 1980 aflagde jeg David Slateet besøg dér vedr. Chess. Bogen Chess Skill in Man and Machine edited by Peter W. Frey, SpringerVerlag, 1977,78 er en klassiker og fokuserer på Chess 4.5

13 Begreberne Shannon type A og B samt MiniMax, Alpha-Beta og Brute Force behandles bl.a. i David E. Welsh: Computer Chess, Wm.C. Brown Publishers, 1984 samt den efterfølgende David E. Welsh og Boris Baczynskyj: Computer Chess II, 1985. David Levy, hvis berømte væddemål på 250 pund i 1968 gik ud på at ingen computer ville vinde over ham de næste ti år (han tabte først i 1978 til Chess 4.7), har bl.a. skrevet 1976 U.S. Computer Chess Chapionship, Computer Science Press, Inc. 1977

14 Chess 3.0 1970, 3.0 1971, 3.6 1972, 4.0 1973, 1974 (2), 4.4 1975, 4.5 1976, 4.6 1977, 4.71978 (2), 4.91979

15 29-årige Garri Kasparov fra Rusland, besteg tronen som verdensmester i skak for over syv år siden

16 40-årig københavnsk lærer. IM 1979. DM 1979 og 1982. Med på det danske OL hold 1978, 1982, 1984 og 1990. Kendt som stemmen bag radioens skakudsendelser

17 IM og tæt på DM. Hører til blandt landets bedste. Skakjournalist. Pressechef ved Deep Blue arrangementet

18 Når man taler om en (historisk) modsætning mellem menneske og automat, taler man dog lidt upræcist. Den historiske udvikling har hidtil ikke været udslag af en bevidst menneskelig stræben, men er forløbet ret automatisk

19 Herbert Schildt: Artificial Intelligence, p9, hvor forestillingen om en computers frie vilje ikke afvises

20 René Descartes 1596-1650, fransk filosof. Kendt for „Jeg tænker, altså er jeg."

21 Villy Sørensen: Den frie vilje, Hans Reitzels Forlag A/S 1992, p79: "Der gives en vilje til frihed og en frihed for vilje: frihed er noget man vil have, når man føler sin ufrihed. Derfor dækker det selvmodsigende udtryk "den frie vilje" meget godt den form for frihed mennesket har der stræber mod at blive frit - og som aldrig helt bliver det, så længe det bliver ved med at være hvad vistadig forstår ved et menneske." 